\title{
Effect of a hyperlipidic diet rich in omegas 3,6 and 9 on aberrant crypt formation in rat colonic mucosa ${ }^{1}$
}

\author{
Efeito de uma dieta hiperlipídica rica em ômegas 3, 6 e 9 na formação de criptas aberrantes em \\ mucosa cólica de ratos
}

\author{
Idália Maria Brasil Burlamaqui', Conceição Aparecida Dornelas", José Telmo Valença Júnior ${ }^{\mathrm{III}}$, Daniel Magalhães Coutinho \\ Mota $^{\text {IV }}$, Francisco José Cabral Mesquita ${ }^{\mathrm{IV}}$, Lara Burlamaqui Verasv, Paulo Roberto Leitão Vasconcelos ${ }^{\mathrm{VI}}$, Lusmar Veras \\ Rodrigues $^{\mathrm{VII}}$
}

'Fellow PhD degree, Postgraduate Program in Surgery, UFC, Brazil. Responsible intellectual and scientific content of the study, manuscript writing, acquisition and interpretation of data.

IIPhD, Full Professor, Department of Pathology and Legal Medicine, UFC, Brazil. Surgical procedures and stereoscopic analysis.

IIIPhD, Full Professor, Department of Pathology and Legal Medicine, UFC, Brazil. Pathological examinations involved in the protocol.

${ }^{\mathrm{IV}}$ Graduate student, UFC, Brazil. Acquisition of data, helped with technical procedures.

${ }^{v}$ Graduate student, Medicine School, Faculdade de Medicina do Juazeiro do Norte, Ceara, Brazil. Review of the literature.

${ }^{\mathrm{V}} \mathrm{PhD}$, Associate Professor, Department of Surgery, UFC, Brazil. Conception, design, intellectual and scientific content of the diets.

${ }^{\mathrm{VII}} \mathrm{PhD}$, Associate Professor, Department of Surgery, UFC, Brazil. Supervised all phases of the study and critical revision.

\begin{abstract}
PURPOSE: To determine whether a hypercaloric and hyperlipidic diet enriched with polyunsaturated fatty acids influences the formation of aberrant crypt foci (ACF) in colonic mucosa of Wistar rats treated with azoxymethane (AOM).

METHODS: At eight weeks of life, the rats were assigned to four groups: Group I—standard diet (STD) not treated with AOM; Group II-hypercaloric and hyperlipidic diet (FED), not treated with AOM; Group III-STD, treated with AOM; Group IV-FED, treated with AOM. At 16 weeks, the animals were injected intraperitoneal with $0.9 \%$ saline solution (Group I and II) or AOM at $15 \mathrm{mg} / \mathrm{Kg}$ (Groups III and IV) once a week for two weeks. Fifteen weeks later, the animals were euthanized.

RESULTS: FED promoted weight gain in Groups II and IV compared to Groups I and III, respectively. The groups did not differ with regard to the total number of ACF. The Chi-square test revealed no predominance of the presence of foci with $\leq 4$ crypts. However, foci with $\geq 5$ crypts were proportionally more prevalent in Group III than in Group IV ( $p=0.043$ ).

CONCLUSION: The administration of polyunsaturated fatty acids did not interfere with the formation of aberrant crypt foci, but reduced ACF multiplicity, exercising an attenuating effect on carcinogenesis.
\end{abstract}

Key words: Dietary Fats, Unsaturated. Azoxymethane. Colorectal Neoplasms. Aberrant Crypt Foci. Rats.

\section{RESUMO}

OBJETIVO: Determinar se uma dieta hipercalórica, hiperlipídica, rica em ácidos graxos poliinsaturados (FED) tem influência na formação de focos de cripta aberrante (FCA) em mucosa cólica de ratos Wistar expostos ao azoximetano (AOM).

MÉTODOS: Com oito semanas de vida, os ratos foram distribuídos em quatro grupos: Grupo I: Dieta padrão (SD) sem AOM; Grupo II: FED, sem AOM; Grupo III: SD, com AOM; Grupo IV: FED com AOM. Com 16 semanas, os animais dos grupos I e II receberam injeções intraperitoneais de solução salina $0,9 \%$, enquanto os dos grupos III e IV receberam AOM na dose de $15 \mathrm{mg} / \mathrm{Kg}$ de peso, 1 vez por semana por duas semanas. Quinze semanas após, os animais foram mortos.

RESULTADOS: FED promoveu aumento de peso nos grupos II e IV em relação aos grupos I e III. Não houve aumento significante no número total de FCA entre os grupos. Em relação à multiplicidade das criptas por FCA, o teste do qui-quadrado mostrou que não houve predominância da presença $\leq 4$ criptas por foco. Contudo, focos $\geq 5$ criptas foram proporcionalmente mais prevalentes no grupo III que no grupo IV $(\mathrm{p}=0,043)$.

CONCLUSÃO: Os ácidos graxos poliinsaturados não interferem na formação de focos de cripta aberrante, contudo reduz sua multiplicidade, exercendo efeito atenuador na carcinogênese.

Descritores: Gorduras Insaturadas na Dieta. Azoximetano. Neoplasias Colorretais. Focos de Criptas Aberrantes. Ratos. 


\section{Introduction}

Even though colorectal cancer (CRC) is the third-most prevalent type of cancer in the world today, its etiology remains largely unknown. The increasing incidence of $\mathrm{CRC}$ has been associated with ageing populations in many countries and changes in life style related to both sedentarism and processed food intake ${ }^{1,2}$.

Obesity is known to be associated with increased risk of cancer in several organs, including the colorectum, through hyperinsulinemia acting directly on the insulin receptors in preneoplastic cells, thereby inducing cell growth. Insulin resistance secondary to hyperinsulinemia generates chronic subclinical inflammation and leads to increased levels of interleukins, prostaglandins and certain cytokines ${ }^{3,4}$.

Experimental studies suggest that CRC is strongly influenced by dietary factors. Thus, ingestion of a fiber and folaterich diet has been shown to reduce the risk of CRC. Calcium has a protective effect as it acts directly on the epithelial colon cells reducing proliferation and inhibiting carcinogenesis ${ }^{5,6}$.

Dietary fat makes up around $40 \%$ of all ingested calories in countries with high incidence of CRC. This is twice the proportion (15-20\%) observed in regions with low incidence of $\mathrm{CRC}$. In fact, there is evidence of a relation between fatty diets and $\mathrm{CRC}$, although the correlation appears to be dependent not only on amount, but also on fatty acid composition ${ }^{7}$.

Research has shown that $\omega-3$ fatty acids, especially eicosapentaenoic acid (EPA) and docosahexaenoic acid (DHA), play a protective role in the development of colorectal cancer and display antiinflammatory activity ${ }^{8,9}$, while $\omega-6$ fatty acids promote carcinogenesis. There is also evidence that $\omega-3$ fatty acids can modulate the formation of eicosanoids and influence the expression of genes, signal transduction molecules and enzyme activity. Peroxisome proliferator-activated receptors (PPARs) are activated by lipophilic compounds such as fatty acids, steroids, vitamin A and D, eicosanoids and drugs. Oxidated EPA is a PPAR- $\alpha$ and PPAR- $\gamma$ agonist with hypolipidemic and antiinflammatory action through the inhibition of nuclear factor kappa-light-chainenhancer of activated B cells (NFKB). Consequently, $\omega-3$ fatty acids can affect cell proliferation and differentiation, apoptosis and angiogenesis ${ }^{10}$. PPAR- $\gamma$ activation induced by diets rich in mono and polyunsaturated fatty acids increases sensitivity to insulin and reduces manifestations of the metabolic syndrome ${ }^{11}$.

Aberrant crypt foci (ACF), first described by Bird ${ }^{12}$, is one of the earliest precursors of colorectal adenomas and cancer in humans ${ }^{12-14}$. In fact, ACF may be observed in the colonic mucosa as early as 2-4 weeks after being induced dose-dependently by specific carcinogenic agents. The increase over time in ACF size and multiplicity is predictive of tumor outcome ${ }^{15}$.

Thus, the purpose of the present study was to evaluate the effect of a hypercaloric and hyperlipidic diet enriched with polyunsaturated fat ( $\omega-3$ and $\omega-9)$ on azoxymethane-induced formation of $\mathrm{ACF}$ in rat colonic mucosa.

\section{Methods}

The study was previously approved by the Federal University of Ceara (UFC) Ethics Committee for Animal Research (CEPA) under protocol \#11/06 and was conducted according to the International Guiding Principles for Biomedical Research Involving Animals.

The experiment used 36 eight-week-old male Wistar rats (Rattus norvegicus albinus, Mammalia, Rodentia, Muridae) weighing 180-250g, supplied by the UFC laboratory animal facility and housed at the UFC laboratory of experimental surgery. The animals were accommodated in individual polypropylene cages under appropriate conditions of moisture, temperature and lighting and had access to food and water ad libitum.

The animals were assigned at random to 4 groups of 9 rats each and fed with one of two diets: a standard diet (STD) (Biobase Biotec $^{\circledR}$ Ratos e Camundongos) providing a total of 3,000 kcal/ $\mathrm{kg}$, or a hypercaloric and hyperlipidic diet (FED) enriched with polyunsaturated fat $(\omega-9: \omega-6=1.5: 1 / \omega-6: \omega-3=3: 1)$ containing $15 \mathrm{~g}$ STD $+20 \mathrm{~g}$ Nutri Diabetic ${ }^{\circledR}+5 \mathrm{~mL}$ canola oil, providing a total of 4,250 kcal/ $\mathrm{kg}$ (Tables 1, 2 and 3).

Carcinogenesis was induced by intraperitoneal (i.p.) administration of two consecutive doses of $15 \mathrm{mg} / \mathrm{Kg}$ azoxymethane one week apart ${ }^{12,13}$.

TABLE 1 - Composition of standard diet (STD): normoglycidic, hyperproteic, hypolipidic.

\begin{tabular}{ccccc}
\hline FOOD & AMOUNT & CHO & PTN & LIP \\
\hline $\begin{array}{c}\text { Biobase } \\
\text { Bio-tec }(\mathrm{g})\end{array}$ & 40 & 17.6 & 8.8 & 1.6 \\
TOTAL $(\mathrm{g})$ & 40 & 17.6 & 8.8 & 1.6 \\
Kcal (\%) & 120 & 70.4 & 35.2 & 14.4 \\
$(100 \%)$ & $(58.66 \%)$ & $(29.34 \%)$ & $(12.00 \%)$ \\
\hline
\end{tabular}

$\mathrm{CHO}=$ carbohydrates $; \mathrm{PTN}=$ protein $; \mathrm{LIP}=$ lipids 
TABLE 2 - Composition of fat-enhanced diet (FED): hypoglycidic, normoproteic, hyperlipidic.

\begin{tabular}{ccccc}
\hline FOOD & AMOUNT & CHO & PTN & LIP \\
\hline $\begin{array}{c}\text { Biobase } \\
\text { Bio-tec }(\mathrm{g})\end{array}$ & 15 & 6.6 & 3.3 & 0.6 \\
$\begin{array}{c}\text { Nutri Diabetic } \mathbb{} \\
(\mathrm{g})\end{array}$ & 20 & 11 & 3.2 & 2.6 \\
$\begin{array}{c}\text { Canola Oil } \\
(\mathrm{g})\end{array}$ & 5 & 0 & 0 & 5 \\
$\begin{array}{c}\text { TOTAL(g) } \\
\text { Kcal }(\%)\end{array}$ & 40 & 17.6 & 6.5 & 8.2 \\
\hline
\end{tabular}

$\mathrm{CHO}=$ carbohydrates $; \mathrm{PTN}=$ protein $; \mathrm{LIP}=$ lipids

TABLE 3 - Lipid profile and ratios between $\omega-3, \omega-6$ and $\omega-9$ fatty acids in STD and FED.

\begin{tabular}{|c|c|c|}
\hline Type of fat & STD & FED \\
\hline Polyunsaturated & $54 \%$ & $19 \%$ \\
\hline Monounsaturated & $24 \%$ & $29 \%$ \\
\hline Saturated & $15 \%$ & $6 \%$ \\
\hline$\omega-9: \omega-6$ & $0.4: 1$ & $1.5: 1$ \\
\hline$\omega-6: \omega-3$ & $8: 1$ & $3: 1$ \\
\hline $\begin{array}{c}\text { Polyunsaturated:Saturated } \\
\qquad \% \omega-6 \text { and } \omega-9\end{array}$ & $\begin{array}{c}5.2: 1 \\
>60 \% \omega-6\end{array}$ & $\begin{array}{c}7.6: 1 \\
>50 \% \omega-9\end{array}$ \\
\hline
\end{tabular}

$\mathrm{STD}=$ standard diet $; \mathrm{FED}=$ fat-enhanced diet

Study design

Prior to the experiment the animals were tagged, weighed and distributed in the following groups:

Group I (GI): Control group, fed with STD, not treated with AOM. The animals were fed with STD from the time of weaning until euthanasia. At 16 weeks, two doses of 1.0 $\mathrm{mL} 0.9 \%$ sterile saline solution (SS) was administered i.p. one week apart. The animals were euthanized in the 31 st week of the experiment.
Group II (GII): Study group, fed with FED, not treated with AOM. The animals were fed with FED from the eighth week of life until euthanasia. At 16 weeks, two doses of 1.0 $\mathrm{mL} 0.9 \% \mathrm{SS}$ was administered i.p. one week apart. The animals were euthanized in the 31 st week of the experiment.

\section{Group III (GIII): Study group, fed with STD, treated} with AOM. The animals were fed with STD from the time of weaning until euthanasia. At 16 weeks, two doses of $15 \mathrm{mg} / \mathrm{kg}$ AOM was administered i.p one week apart. The animals were euthanized in the 31 st week of the experiment.

\section{Group IV (GIV): Study group, fed with FED, treated} with AOM. The animals were fed with FED from the eighth week of life until euthanasia. At 16 weeks, two doses of $15 \mathrm{mg} /$ $\mathrm{kg}$ AOM was administered i.p. one week apart. The animals were euthanized in the 31 st week of the experiment.

\section{Surgical procedure and euthanasia}

Fifteen weeks after the first dose of AOM, the animals were anesthetized with $80 \mathrm{mg} / \mathrm{Kg}$ ketamine and $8 \mathrm{mg} / \mathrm{Kg}$ xylazine i.p., placed in dorsal decubitus in preparation for surgery and submitted to laparotomy by xypho-pubic median incision and exposure of the peritoneal cavity for protocolectomy. The excised specimens were measured, weighed, opened longitudinally opposite the mesocolon, washed with SS, laid out on kraft filter paper, rolled up along the axis and immersed in a $10 \%$ formaldehyde solution for fixation. Subsequently, the animals were euthanized by hypovolemic shock by sectioning the abdominal aorta.

The colon was then divided into three segments of equal size (distal, middle and proximal) and stained with $0.1 \%$ methylene blue in phosphate buffered saline for one minute ${ }^{12}$. Following Bird's method, the ACF were counted by the same researcher using a stereo microscope (DF Vasconcellos M90, Vasconcellos S.A.) at $40 x$.

\section{Statistical analysis}

Analyses were carried out with the software SPSS v.16.0 for Windows ${ }^{\circledR}$. Comparisons between three or more independent groups were performed with ANOVA or the Kruskal Wallis test. Student's $t$ test was used for pairwise comparisons with regard to average weight. The Chi-square test was used to verify the homogeneity of Groups III and IV with respect to ACF multiplicity. 
The level of statistical significance was set at $\mathrm{p}<0.05$.

\section{Results}

The groups were compared with regard to weight, macroscopic aspects and microscopic findings (number and multiplicity of ACF).

\section{Weight distribution}

The average weight was not significantly different between Groups I and II ( $p=0.711)$ or between Groups III and IV $(p=0.417)$ at baseline. However, by the end of the experiment the average weight was greater in Group II than in Group I ( $p=0.000)$ and greater in Group IV than in Group III ( $p=0.028$ ) (Table 4).

TABLE 4 - Weight $(\mathrm{g})$ distribution in Groups I, II, III and IV at 8 weeks and 31 weeks.

\begin{tabular}{cccc}
\multicolumn{5}{c}{ Average weight (g) \pm SD } \\
Groups & $\mathrm{n}$ & $\begin{array}{c}\text { Baseline (8 } \\
\text { weeks) }\end{array}$ & $\begin{array}{c}\text { End point (31 } \\
\text { weeks) }\end{array}$ \\
\hline I & 9 & $200.8 \pm 11.1$ & $385.0 \pm 16.4$ \\
II & 9 & $203.4 \pm 17.0$ & $431.6 \pm 20.1^{\#}$ \\
III & 9 & $253.0 \pm 16.6$ & $417.1 \pm 26.2$ \\
IV & 9 & $245.7 \pm 19.9$ & $468.8 \pm 58.8^{*}$ \\
\hline
\end{tabular}

$\mathrm{SD}=$ standard deviation

\# Average weight was greater in Group II than in Group I by the end of the experiment $(p=0.000)$

* Average weight was greater in Group IV than in Group III by the end of the experiment $(p=0.028)$

(Student's $t$ test)

\section{Stereomicroscopic findings}

\section{Aberrant crypt foci}

Significant differences in ACF total numbers were observed for Group III between the proximal and the middle segment $(\mathrm{p}=0.000)$, between the proximal and the distal segment $(\mathrm{p}=0.006)$ and between the middle and the distal segment $(p=0.048)$. Likewise, significant differences were found for Group IV between the proximal and the middle segment $(\mathrm{p}=0.000)$ and between the proximal and the distal segment $(\mathrm{p}=0.000)$ (Table 5). Groups III and IV did not differ significantly with regard to the total number of ACF in the entire specimen $(p=0.933)$ (Table 6).

TABLE 5 - Average total number of ACF per colon segment in Groups I, II, III and IV.

Number of $\mathrm{ACF} \pm \mathrm{SD}$

Proximal Middle Distal

\begin{tabular}{cccc}
\hline Group I & $0.67 \pm 1.32$ & 0 & $0.22 \pm 0.66$ \\
Group II & 0 & 0 & $0.22 \pm 0.44$ \\
& & & \\
Group III & $0.33 \pm 1$ & $57.44 \pm$ & $33.22 \pm$ \\
& & $27.5^{\bullet}$ & $19.63^{\dagger} \partial$ \\
Group IV & $2.22 \pm$ & $47.78 \pm$ & $42.44 \pm$ \\
& 2.63 & $20.45^{*}$ & $14.4^{\#}$ \\
\hline
\end{tabular}

$\mathrm{SD}=$ standard deviation

- In Group III the proximal and middle segments differed significantly $(p=0.000)$

$\dagger$ In Group III the proximal and distal segments differed significantly $(p=0.006)$

$\partial$ In Group III the distal and middle segments differed significantly $(p=0.048)$

* In Group IV the proximal and middle segments differed significantly $(p=0.000)$

\# In Group IV the proximal and distal segments differed significantly $(p=0.000)$

TABLE 6 - Total number of ACF in Groups III and IV.

\begin{tabular}{lcccc}
\hline & Minimum & Maximum & Average & SD \\
\hline Group III & 44 & 167 & 91.00 & 38.47 \\
Group IV & 37 & 144 & 92.44 & 33.38 \\
\hline
\end{tabular}

$\mathrm{SD}=$ standard deviation

The total number of ACF did not differ significantly between the two groups $(p=0.933)$

\section{ACF multiplicity in groups treated with AOM}

Groups III and IV did not differ significantly with regard to the total number of ACF with $\leq 4$ crypts, but differed with regard to the total number of ACF with $\geq 5$ crypts ( $p=0.043$ ) (Table 7$)$. 
TABLE 7 - Number of ACF with $\leq 4$ crypts and ACF with $\geq 5$ crypts in Groups III and IV.

\begin{tabular}{cccc}
\hline $\begin{array}{c}\text { Number of } \\
\text { crypts per focus }\end{array}$ & Group III & Group IV & Total \\
\hline$\leq 4$ crypts & 762 & 792 & 1554 \\
$\geq 5$ crypts & $60(7.30 \%)^{*}$ & $40(4.81 \%)$ & 100 \\
Total & 822 & 832 & 1644 \\
\hline
\end{tabular}

The proportion of foci with $\geq 5$ crypts was greater in Group III than in Group IV $\left(\chi^{2} \mathrm{cc}=4.091 ; p=0.043^{*}\right)$ Yates' chi-square test

\section{Discussion}

CRC in humans is in many cases related to feeding habits: dietary substances such as saturated fats and $\omega-6$ fatty acids favor the development of dysplasia in the crypts of the colonic mucosa and can promote carcinogenesis, while diets rich in polyunsaturated fat, -3 and $\omega-9$ fatty acids, insoluble fibers, certain vitamins (D, A, C, E and $\beta$-carotene), minerals (calcium, selenium) and antioxidants (folates, flavonoids) may reduce the incidence ${ }^{16-18}$. It is estimated that CRC is causally associated with environmental factors, especially diet-related factors, in $80 \%$ of cases $^{19}$.

The animals in Group I and III were fed a normocaloric $(3,000 \mathrm{kcal} / \mathrm{kg})$ standard diet (Biobase Biotec ${ }^{\circledR}$ Ratos e Camundongos; $\omega-9: \omega-6=0.4: 1 ; \omega-6: \omega-3=8: 1$; polyunsaturated: saturated fat $=5.2: 1)$ (Tables 1 and 3 ). The animals in Group II and IV were fed a hyperlipidic and hypercaloric diet $(4,250$ $\mathrm{kcal} / \mathrm{kg})$ rich in polyunsaturated fat $(\omega-9: \omega-6=1.5: 1 ; \omega-6: \omega-3=$ $3: 1$; polyunsaturated/saturated fat $=7.6: 1)$ enriched with fibers, minerals and vitamins (Tables 2 and 3 ).

The hyperlipidic and hypercaloric diet used in this study resembles the Mediterranean diet (rich in -3 fatty acids, $>50 \% \omega-9$ fatty acids, low in saturated fat) which is known to be toxin-free and protective against cardiovascular disorders ${ }^{20-22}$. Similar diets have been shown to influence colorectal carcinogenesis ${ }^{23-25}$. The present study tested the ability of a hyperlipidic and hypercaloric diet to inhibit the development of ACF in the colonic mucosa of rats treated with $\mathrm{AOM}$.

The study diet (FED) contained $>50 \% \omega-9$ fatty acids (Table 3). Diets of this type tend to reduce oxidative stress, because oleic acid (which has only one double carbon bond) produces less reactive oxygen species when oxidated ${ }^{26}$.

The $\omega-9:-6$ ratio was 1.5:1 for FED and 0.4:1 for STD (Table 3). This probably contributed to reducing inflammation, and thereby carcinogenesis, in the colonic mucosa of rats treated with AOM.

The diets used in the study produced no clinical impact, such as diarrhea or abdominal distension. However, animals receiving FED (Group II and IV) and animals receiving STD (Group I and III) differed significantly with regard to final weight and evolution in weight gain, as shown by differences observed between Group I (STD) and Group II (FED) and between Group III (STD+AOM) and Group IV (FED+AOM) at the onset of AOM administration and by the end of the experiment (Table 4). It may thus be inferred that $\mathrm{AOM}$ at $15 \mathrm{mg} / \mathrm{kg}$ did not interfere with food ingestion nor affect the final weight of the animals.

In spite of the greater weight gain observed in Group IV compared to Group III, no significant increase was observed in the total number of ACF in the middle segment $(p=0.985)$ or distal segment $(p=0.854)$ or in the total number of crypts or foci in the entire colonic mucosa ( $p=0.933$ vs. $p=0.893$, respectively) (Tables 5 and 6). This diverges from results published by other researchers showing that hypercaloric diets and obesity favor tumor growth ${ }^{4,27-29}$.

In our study, Groups III and IV did not differ significantly with regard to ACF multiplicity when foci with $\leq 4$ crypts were considered for the entire colonic mucosa. However, foci with $\geq 5$ crypts were proportionally more prevalent in Group III than in Group IV ( $p=0.043$ ) (Table 7$)$, suggesting the study diet (FED) was protective against carcinogenesis.

Diets enriched with $\omega-3$ fatty acids ( $\alpha$-linolenic acid, EPA and DHA - polyunsaturated fats with antiinflammatory and immunoregulatory action) suppress the Akt/mTOR and NFאB pathways and prevent tumor cell proliferation. In addition, oxidated EPA (a PPAR- $\gamma$ agonist) plays an important role in apoptosis ${ }^{30}$.

Omega 3 and 6 fatty acids have been shown to have opposite regulatory effects on $\mathrm{k}-\mathrm{ras}^{31}, \mathrm{Bcl}-2^{32}$ and $\mathrm{Bax}^{33}$ (proteins involved in the regulation of cell proliferation and apoptosis) and to influence induced NOS activity ${ }^{10}$. iNOS is positively correlated with COX-2 expression and angiogenesis ${ }^{34,35}$. iNOS activity with excessive nitric oxide production can also inhibit the activity of DNA repair enzymes and modulate the activity of caspases and $\mathrm{p} 53^{36}$. DHA can reduce the expression of iNOS in vitro ${ }^{37}$. Most researchers have used $\omega-3$ extracted from fish. In this study vegetable $\alpha$-linolenic acid was used as the principal source.

Shirtiliff and Bird suggested that foci with a greater number of crypts are at higher risk of becoming neoplastic as they 
reflect the proliferation process of early lesions ${ }^{38}$. If so, the number of crypts per ACF may be a relatively precise indicator of the risk of tumor development ${ }^{39,40}$.

The present study shows that, in spite of the weight gain observed, the study diet (FED) did not interfere in the development and proliferation of ACF in the entire colonic mucosa, but it significantly inhibited the development of foci with 5 or more crypts, suggesting a protective effect against the development of neoplastic cells.

\section{Conclusion}

The administration of a diet enriched with polyunsaturated $\omega-3$ and -9 fatty acids did not interfere with the generation of AFC but reduced ACF multiplicity, producing an attenuating-thus beneficial-effect on colorectal carcinogenesis.

\section{References}

1. World Health Organization (WHO). Global cancer rates could increase by $50 \%$ to 15 million by 2020 . Geneva; 2003 .

2. American Cancer Society. Cancer Facts \& Figures. Atlanta: American Cancer Society; 2007.

3. Carvalheira JBC, Saad MJA. Doenças associadas à resistência à insulina/hiperinsulinemia não incluídas na síndrome metabólica. Arq Bras Endocrinol Metab. 2006;50:360-7.

4. Puerta R, Marquez-Martin A, Fernandez-Arche A, Ruiz-Gutierrez $\mathrm{V}$. Influence of dietary fat on oxidative stress and inflammation in murine macrophages. Nutrition. 2009;25:548-54.

5. Pasi AJ, Mayer RJ Chemoprevention of colorectal cancer. N Engl J Med. 2000;342:1960-8.

6. Santarelli RL, Pierre F, Corpet DE. Processed meat and colorectal cancer: a review of epidemiologic and experimental evidence. Nutr Cancer. 2008;60:131-44.

7. Campos FG, Waitzberg DL, Logullo-Waitzberg AF, Habr-Gama A, Kiss DR, Gama-Rodrigues, J. Diet and colorectal cancer: current evidence for etiology and prevention. Nutr Hosp. 2005;20:18-25.

8. Sierra S, Lara-Villoslada F, Comalada M, Olivares M, Xaus J. Dietary eicosapentaenoic acid and docosahexaenoic acid equally incorporate as decosahexaenoic acid but differ in inflammatory effects. Nutrition. 2008;24:245-54.

9. Mernitz H, Fuzhi L, Smith DE, Meyadani SN, Wang X. Fish oil supplementation inhibits NNK-induced lung carcinogenesis in the A/J mouse. Nutr Cancer. 2009;61:663-9.

10. Roynette CE, Calder PC, Dupertuis YM, Pichard C. N-3 polyunsaturated fat acids and colon cancer prevention. Clin Nutr. 2004;23:139-51

11. Sauma L, Stenkula KG, Kjølhede P, Strålfors P, Söderström M, Nystrom FH. PPAR- $\gamma$ response element activity in intact primary human adipocytes: effects of fatty acids. Nutrition. 2006;22:60-8.

12. Bird RP. Observation and quantification of aberrant crypts in the murine colon treated with a colon carcinogen: preliminary findings. Cancer Lett. 1987;37:147-51.

13. Bird RP. Role of aberrant crypt foci in understanding the pathogenesis of colon cancer. Cancer Lett. 1995;93:55-71.

14. Adler DG, Gostout CJ, Sorbi D, Burgart LJ, Wang L, Harmsen WS
Endoscopic identification and quantification of aberrant crypt foci in the human colon. Gastrointest Endosc. 2002;56:657-62.

15. Bird RP, Good CK. The significance of aberrant crypt foci in understanding the pathogenesis of colon cancer. Toxicol Lett. 2000;15:112-3.

16. Nkondjock A, Shatenstein B, Maisonneuve, P, Ghadirian, P. Specific fatty acids and human colorectal cancer: an overview. Cancer Detect Prev.2003;27(1):55-66.

17. Vinikoor LC, Satia JA, Schroeder JC, Millikan RC, Martin CF, Ibrahim JG, Sandler RS. Associations between trans fatty acid consumption and colon cancer among Whites and African Americans in the North Carolina colon cancer study I. Nutr Cancer. 2009;61:427-36.

18. Tanaka T, Kohno H, Mori H. Chemoprevention of colon carcinogenesis by dietary non-nutritive compounds. Asian Pac J Cancer Prev. 2001;2:1-13.

19. Higginson J. Environmental carcinogenesis. Cancer. 1993;72:9717.

20. Shai I, Schwarzfuchs D, Henkin Y, Shahar DR, Witkow S, Greenberg I, Golan R, Fraser D, Bolotin A, Vardi H, Tangi-Rosental O, ZukRamot R, Sarusi B, Brickner D, Schwartz Z, Sheiner E, Marko R, Katorza E, Thiery J, Fiedler GM, Blüher M, Stumvoll M, Stampfer MJ. Weight loss with a low-carbohydrate, mediterranean, or low-fat diet. N Engl J Med. 2008;359:229-41.

21. Pelucchi C, Bosetti C, Rossi M, Negri E, La Vecchia C. Selected aspects of mediterranean diet and cancer risk. Nutr Cancer. 2009;62:756-66.

22. Djuric Z, Ren J, Blythe J, VanLoon G, Sen A. A Mediterranean dietary intervention in healthy American women changes plasma carotenoids and fatty acids in distinct clusters. Nutr Res. 2009;29:156-63.

23. Calviello G, Serini S, Piccioni E. N-3 polyunsaturated fatty acids and the prevention of colorectal cancer: molecular mechanisms involved. Curr Med Chem. 2007;14:3059-69.

24. Dupertius YM, Meguid MM, Pichard C. Colon cancer therapy: new perspectives of nutritional manipulations using polyunsaturated fatty acids. Curr Opin Clin Nutr Metab Care. 2007;10:427-32.

25. Liang B, Wang S, Ye YJ, Yang XD, Wang YL, Qu J, Xie QW, Yin MJ. Impact of postoperative omega-3 fatty acids supplemented parenteral nutrition on clinical outcomes and immunomodulations in colorectal cancer patients. World J Gastroenterol. 2008;14:24349.

26. Fang YZ, Yang S, Wu G. Free radicals, antioxidants and nutrition. Nutrition. 2002;19:872-9.

27. International Agency for Research on Cancer (IARC). Handbooks of cancer prevention, weight control and physical activity. Lyon; 2002.

28. Calle EE, Kaaks R. Overweight, obesity and cancer: epidemiological evidence and proposed mechanisms. Nat Rev Cancer. 2004;4:57991.

29. Renehan AG, Tyson M, Egger M, Heller RF, Zwahien M. Bodymass index and incidence of cancer: a systematic review and metaanalysis of prospective observational studies. Lancet. 2008;371:56978.

30. Tang FY, Cho HJ, Pai MH, Chen YH. Concomitant supplementation of lycopene and eicosapentaenoic acid inhibits the proliferation of human colon cancer cells. J Nutr Biochem. 2009;20:426-34.

31. Davidson LA, Lupton JR, Jiang YH, Chapkin RS. Carcinogen and dietary lipid regulate ras expression and localization in rat colon without affecting farnesylation kinetics. Carcinogenesis. 1999;20:785-91.

32. Llor X, Pons E, Roca A, Àlvarez M, Mañé J, Fernández-Bañares F, Gassull MA. The effects of fish oil, olive oil, oleic acid and linoleic 
acid in colorectal neoplastic processes. Clin Nutr. 2003;22:71-9.

33. Cheng J, Ogawa K, Kuriki K, Yokoyama Y, Kamiya T, Seno K, Okuyama H, Wang J, Luo C, Gujii T, Ichikawa H, Shirai T, Tokudome S. Increased intake of n-3 polyunsaturated fatty acids elevates the level of apoptosis in the normal sigmoid colon of patients polypectomized for adenomas/tumors. Cancer Lett. 2003;193:1724.

34. Cianchi F, Cortesini C, Fantappie O, Messerini L, Schiavone N, Vannacci A, Nistri S, Sardi I, Baroni G, Marzocca C, Perna F, Mazzanti R, Bechi P, Masini E. Inducible nitric oxide synthase expression in human colorectal cancer. Am J Pathol. 2003;162:793801.

35. Cianchi F, Cortesini C, Fantappie O, Messerini L, Sardi I, Lasagna N, Perna F, Fabbroni V, Di Felice A, Periglini G, Mazzanti R, Masini E. Cyclooxygenase-2 activation mediates the proangiogenic effect of nitric oxide in colorectal cancer. Clin Cancer Res. 2004;10:2694704.

36. Jaiswal M, Larusso NF, Burgart LJ, Gores GJ. Inflammatory cytokines induce DNA damage and inhibit DNA repair in cholangiocarcinoma cells by a nitric oxide-dependent mechanism. Cancer Res. 2000;60:184-90.

37. Narayanan BA, Narayanan NK, Simi B, Reddy BS. Modulation of inducible nitric oxide synthase and related proinflammatory genes by the omega- 3 fatty acid docosahexaenoic acid in human colon cancer cells. Cancer Res. 2003;63:972-9.

38. Shirtliff N, Bird RP. Growth features of aberrant crypt foci that resist modulation by cholic acid. Carginogenesis. 1996;17:2093-6.

39. Corpet DE, Stamp D, Medline A, Minkin S, Archer MC, Bruce WR. Promotion of colonic microadenoma growth in mice and rats fed cooked sugar or cooked casein and fat. Cancer Res. 1990;50:6955-8.

40. Pretlow TP, O'Riordan MA, Somich GA, Amini SB, Pretlow TG. Aberrant crypts correlate with tumor incidence in F344 rats treated with azoxymethane and phytate. Carcinogenesis. 1992;13:1509-12.

\section{Acknowledgements}

This study was supported by the following Brazilian agencies: Surgery Postgraduate Program of Federal University of Ceara and the Experimental Surgery Laboratory (LABCEX), Medical School, Federal University of Ceara.

\section{Correspondence:}

Idália Maria Brasil Burlamaqui

Av. Beira Mar, 3680/2001

60165-121 Fortaleza-CE Brazil

Tel.: (55 85)3267-5780

idaliaburlamaqui87@hotmail.com

Received: August 09, 2011

Review: October 10, 2011

Accepted: November 14, 2011

Conflict of interest: none

Financial source: National Council for Scientific and

Technological Development (CNPq)

${ }^{1}$ Research performed at Postgraduate Program in Surgery,

Medical School, Federal University of Ceara (UFC), Brazil. Part of Master thesis. Tutor Lusmar Veras Rodrigues. 